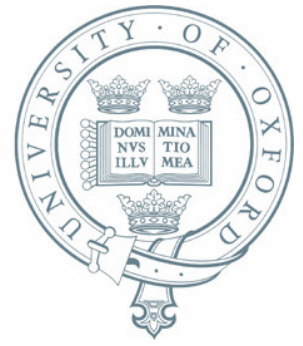

Working papers

\title{
Comparing the Experience of Five Major Emigration Countries
}

\author{
Stephen Castles
}




\title{
Comparing the Experience of Five Major Emigration Countries
}

Note: This paper was originally prepared for a workshop held in Bellagio (Italy), with the support of the Rockefeller Foundation, in July 2006. The paper was revised following discussions with the other participants at Bellagio, and was subsequently presented at the Conference Migration And Development: A Comprehensive Perspective From the South, held in Mexico City, with the support of the Fundación BBVA Bancomer, in February 2007. It is published here (together with other papers from the Bellagio Workshop) as an IMI Working Paper. These papers will subsequently be published as a book in both English and Spanish, under the title: Migration and Development: Perspectives from the South.

\begin{abstract}
This paper summarises and compares the findings of studies of five major emigration countries India, Mexico, Morocco, the Philippines and Turkey. It discusses the extent to which the five countries share significant common characteristics, so that a comparative analysis may provide useful insights into migratory processes. The paper takes up the debate on migration and development that has become so prominent in international policy circles. An attempt is made to examine the extent to which migration has actually contributed to development in the five countries of origin. The general conclusion is that migration is itself a result of processes of social transformation linked to globalisation and the post-colonial re-ordering of economic and political relationships. In turn, migration becomes a factor in further processes of transformation. Thus migration should be included in strategies for achieving change, but the conditions for realising positive results are complex and difficult. Strategies of 'remittance-led development' seem simplistic and naïve. Migration alone cannot remove structural constraints to sustainable economic growth. There is a need for broadly-based long-term approaches that links the potential benefits of migration with more general strategies to reduce inequality and to improve economic infrastructure, social welfare and political governance.
\end{abstract}

Key Words: Migration, development, social transformation, remittances, diasporas, return

Stephen Castles, Co-Director and Senior Researcher

International Migration Institute

James Martin $21^{\text {st }}$ Century School

University of Oxford

Stephen.castles@qeh.ox.ac.uk 


\section{Introduction}

The five country studies presented at the Bellagio Workshop provide analyses of emigration from some of the world's major countries of origin. They give important insights into the experience of migrants and their communities. More broadly, they help us to understand the complex relationships between global change, migration and development. The studies show the diversity and complexity of the migration experience, and the way it transforms lives and builds enduring links across national boundaries. The purpose of this comparative paper is to build on these analyses to bring out both differences and similarities in the emigration experience and its effects on the societies concerned, as well as their relations with the receiving countries. ${ }^{1}$

This raises the question whether such a comparison can be useful in view of the important differences between the five countries with regard to history, culture, economic development, and international relations? Indeed, one might go further and ask whether such a comparison is really possible if the differences are so great? This comparative essay is an attempt to answer these questions. A first objective of the paper is thus to see if these five major emigration countries share significant common characteristics so that analysts, policy-makers and practitioners can gain important insights from the comparison. Another important issue relates to the new discourse on migration and development that has become so prominent in international policy circles in recent years. One of the main tasks of the country studies was to examine the extent to which migration does contribute to development. A second objective of this paper is thus to summarise the varying evidence on migration and development and to attempt to generalise from it.

\footnotetext{
1 This is based on the five studies presented at the Bellagio workshop It therefore makes no claim to be the result of original research. I thank the authors of the five country studies for allowing me to use their work. I also thank Hein de Haas, Binod Khadria, Kemal Kirisci and Raúl Delgado Wise for specific comments on the draft versioin. The interpretations are my own responsibility. My text will not make repeated references to the country studies (unless they are quoted directly), nor to their sources.
} 


\section{The forces driving emigration}

What makes people leave their countries to seek a better life abroad? One can summarise the reasons under the headings of demography, economics (or better: political economy) and politics.

The five countries vary considerably in population size from Morocco's 31 million to the quite large populations of Turkey (73m), Philippines (83m) and Mexico $(107 \mathrm{~m})$, while India is one of the world's two population giants with 1.1 billion people in 2005 (UN Population Division 2006). What unites them is the relative recentness of the 'demographic transition' from the high fertility and high mortality patterns typical of less-developed agrarian countries, to the rapidly declining mortality, increasing life expectancy and rapid population growth brought about by modernisation. All five countries have had numerous young labour force entrants. There has been complementarity with demographic trends in highly-developed labour-importing countries, where fertility has declined sharply, life expectancy has increased even more, and rates of age dependency (ratio of retired people to working age to population) have grown fast. Fertility is now also declining in the five emigration countries - although less so in India and the Philippines - so that population growth will peak in the foreseeable future. The five countries studied have been important labour reservoirs for richer economies, but may cease to be so between about 2025 and 2050. This could mean decline of migration or even reverse flows in future - or it could take the form noted in Mexico: depopulation of rural areas, to the point where future development is blocked.

Demography is always only one side of the migration picture. Why have the economies not grown fast enough to offer jobs to the new entrants? All five country studies note blocked or uneven economic development. In the cases of India and Mexico, reference is made to the failure of past strategies of import-substitution industrialisation (that is the attempt to develop national industry behind tariff barriers). In India this strategy created a large state sector and high levels of regulation, causing stagnation, low growth, low exports, poor wages and lack of jobs for both skilled and unskilled workers. In Turkey state inefficiency, political and ethnic conflict, poor infrastructure and corruption had similar effects. In the 1960s, the Philippines were widely expected to be on the brink of 'economic take-off' due to 
its high levels of education and good international connections. This hope was dashed by a mixture of dictatorship (the Marcos regime), political instability and lack of foreign direct investment (FDI) - the last being probably a result of the previous factors.

More recently, the neo-liberal 'Washington Consensus' strategies of liberalisation of capital and commodity markets, privatisation of industry and services and reductions in social expenditure have led to some degree of economic stabilisation, but have not created enough jobs. On the contrary, structural adjustment can itself be a factor reducing employment and encouraging emigration (Adepoju, 2006). The Mexican paper notes that the introduction of the North American Free Trade Agreement (NAFTA) has been the basis for a neo-liberal integration of the Mexican and US economies - to the exclusive benefit of the latter. The maquiladora system of siting plants producing for the US market just inside the Mexican border has put low-cost Mexican labour at the service of US companies, without doing anything to reduce northwards migration.

Thus the political economy of emigration has been rather similar. Three of the five countries had experienced direct colonial control: India by Britain, Morocco by France and Spain, the Philippines by the USA. Two had been subject to powerful semi-colonial influences: Mexico by the USA from the $19^{\text {th }}$ century, Turkey by European powers, especially Germany, Britain and France, from the early $20^{\text {th }}$ century. In the post-1945 period, the five countries have experienced economic domination in the successive forms of neo-colonialism, multinational control of agriculture and industry, and, most recently, globalisation. The results have been uneven development, impoverishment of certain groups, rural-urban migration and onward migration to industrial countries.

In some of the countries, politics has played an even more direct role. In the 1960s and 1970s, the Moroccan monarchy saw emigration as a safety valve for discontent, especially among the Berbers (who make up a large share of the Moroccan population). As de Haas points out (in this volume) most emigration was from the eastern part of the Rif Mountains and other predominantly Berber regions. The Marcos dictatorship in the Philippines started a systematic labour export programme partly in the hope of reducing discontent with the predatory character of the regime and its inability to improve living standards for the masses. Turkish emigration was partly linked to both political and ethnic conflict. In the 1970s and 1980s, many 
emigrants were seeking to escape successive military regimes and their crackdown on labour unions and democratic organisations. From the 1990s, many of the emigrants and asylum seekers were ethnic Kurds, seeking refuge from the violence and persecution of the conflict between the Turkish state and Kurdish nationalists.

\section{Migration and social transformation}

Before talking about migration and development, it is necessary to question the very notion of development, which in its constant repetition by governments and international agencies seems to have taken on the character of a common sense statement that needs no explanation or justification. Development is often tacitly equated with positive change in the teleological sense of emulation of successful western models of economic growth, together with the social and political institutions and values that appear to have underpinned these. But it is often forgotten that the precondition for industrial revolutions in Europe and North America was the forced transfer of resources from the rest of the world in the colonial era. Control of labour resources and the ability to move these where they were needed for capital accumulation were crucial aspects of modernisation.

The factors driving migration are thus part of the broad processes of social transformation that have affected the societies of Africa, Asia and Latin America, as they have been drawn into the world economic and political system created by the cultural and technological domination of Western Europe and North America since the $16^{\text {th }}$ century (Castles, 2007). The stages of this process have included colonialism, imperialism, decolonisation and neo-colonialism and now globalisation. A necessary precondition for the development of the North has been the underdevelopment of the South through the transfer of crucial resources to the former. Control of southern labour by northern states and employers has always been part of this transaction, whether in the form of slavery, forced labour in plantations or recruitment for mines (Rodney, 1972). The transfer of labour power and skills to the rich countries through labour migration is the latest form of development aid by the South to the North, so 
one may wonder why it is portrayed by states and international agencies as an important factor in the development of the countries of origin.

It therefore seems more appropriate to analyse migration as part of the broad social transformation processes that affect all societies (both North and South) in the epoch of accelerated global integration. People emigrate because the social transformation of their countries of origin radically changes their conditions of life and work, while parallel transformations of destination countries create demand for labour. In turn migration becomes a factor in the relationships between societies and in further changes within them. Such processes of change are too complex to be subsumed into the notion of development, especially as they are multi-dimensional and may well have negative outcomes for many of the people involved. At the very least, it is always important to ask 'what is the real content of development' and 'how does it affect various social groups? In this paper, the term development cannot be avoided, for it is constantly used in discourse, but it is important to remember the need for deeper-going analysis and broader-based action. If migration is to benefit the countries of origin, important conditions must be met with regard to fair exchange, safeguarding of human rights and transfer of resources back to migrants' homelands.

Globalisation and social transformation lead to new forms of labour market incorporation at various spatial levels. Penetration of southern economies by global capital causes the restructuring of production processes, in which some groups of producers are included and experience higher incomes, while other groups find their workplaces eliminated and their skills devalued. Subsistence agriculture declines, while market-driven cash crop production requires considerable capital inputs, leading to the concentration of land ownership in the hands of large farmers (who themselves become dependent on multinational agribusiness giants). Displaced rural workers migrate to the towns, fuelling the burgeoning mega-slums of Africa, Asia and Latin America. Low wages and lack of real jobs make life precarious and risky for these new town-dwellers. In many cases, impoverishment is compounded by the corruption, violence and repression of weak and dictatorial regimes. The failure to incorporate rural-urban migrants into urban labour markets and societies leaves cross-border migration as an obvious way out.

Much of this is south-south economic migration: e.g. Egyptians and Moroccans to oil-rich Libya, Mozambicans to South Africa or Filipinos to Malaysia. Another part is regional forced migration in search of protection: e.g. Burundians to 
Tanzania, Tibetans to India, or Colombians to Venezuela. Much of the migration involves 'mixed motivations' - people fleeing persecution and seeking economic improvement. However, an increasing proportion is South-North migration. This can be regional or global in scope. Regional labour markets are significant for Mexico, with migration predominantly to the big northern neighbour; for Morocco, whose workers used to go mainly to France, Belgium and the Netherlands, and more recently to Spain and Italy too; and for Turkey, with past major movements to Germany and the Netherlands and smaller ones to Belgium, France and Switzerland, and current mobility to the Gulf oil states, Russia and some Central Asian countries.

By contrast, Indian and Filipino emigrants are dispersed globally to many destinations. Highly-skilled Indians go mainly to the USA, but also to Canada, Australia, the UK and other European countries. The lower-skilled go mainly to the Gulf, but also to Europe, Japan, Singapore and Malaysia. Migrants from the Philippines are to be found in all highly-developed countries, but also in the Gulf, the new Asian industrial countries and Japan. Filipina domestic workers are ubiquitous, while Filipino seafarers crew ships sailing under many flags. As the Philippines study (in this volume) points out, officials in that country proudly portray it as the 'producer of workers for the world'. ${ }^{2}$

\section{Migration history}

Only about 3 per cent of the world's population are international migrants, but migration is uneven: certain countries have become major sources of emigrants. What makes a country into a labour reservoir for the developed countries? In most cases, this is not a sudden change, but rather the culmination of long historical processes. Migration is not a new phenomenon: all the countries dealt with here had pre-modern patterns of temporary mobility for agricultural, trade, cultural and religious purposes,

\footnotetext{
${ }^{2}$ In the Moroccan study, de Haas draws attention to the 'migration systems approach' as a way of analysing international migration (see also Kritz et al., 1992). Without going into detail here, that approach seems to fit best to the regional systems affecting Mexico, Morocco and Turkey. It is harder to apply where migrants from one source are as widely dispersed as Indians and Filipinos. However, a detailed analysis of specific components of these migrations - e.g. Indian IT professionals in California or Filipino medical personnel in the UK or Filipina entertainers in Japan - might well benefit from the migration systems framework.
} 
and of more permanent movement as a result of warfare, environmental factors or economic change. However, it was colonialism that paved the way for modern migratory movements. The colonial rulers made India into a major source of indentured workers and soldiers for the rest of the British Empire in the $19^{\text {th }}$ century (Cohen, 1995). Moroccan migration to France was started by colonial recruitment of soldiers and labourers for the First World War. US employers recruited plantation labourers for Hawaii in the Philippines from the early 20th century. Mexico in its modern form is itself a product of the colonisation of the New World. More recently, the Mexican study draws attention to a succession of phases of "neo-colonial migration' based on US economic dominance since the late $19^{\text {th }}$ century.

Turkey is something of an exception here: in the Ottoman period it was an immigration area, attracting both economic migrants (like Genovese merchants) and persecuted religious minorities. These included Jews expelled from Spain from 1492 onwards, and then, in the $19^{\text {th }}$ century, Muslim groups fleeing to the 'heartland' of the Empire as Ottoman power declined. The establishment of the Turkish nation-state after WWI led to immigration of ethnic Turks and Muslims from the surrounding region. Large-scale labour emigration did not start until the 1960s, and was a result of state action, in the form of efforts of the German and Dutch labour market authorities to recruit workers, and the eagerness of the Turkish Government to find a palliative for unemployment. This points to the double-sided causality of contemporary labour migration. Indian migration to Britain was a result both of lack of opportunities in the country of origin and strong demand for labour for the still important manufacturing industries of the UK in the 1950s and 1960s. The Indian brain-drain in this period also resulted from this combination of poor prospects at home and demands for specialists in developed countries.

Similarly, Mexican migration to the USA got underway during and after WWII as a result of the bracero programme, introduced by US authorities to meet employers' labour demand for large-scale agriculture. Moroccan migration to Western Europe was started by labour recruitment to France, following old colonial patterns, quickly joined by 'guestworker' recruitment for the Netherlands, Belgium and Germany. Philippines labour migration seems to have received an initial impetus from government policies, but then became a self-generating process in which strong labour demand, the good reputation of Filipino workers and the continuing lack of jobs at home worked together. 
Again this points to a pattern: however movements started, they tended to become self-sustaining, due to a combination of employer demand and structural dependence on foreign labour in receiving areas, and expectations of mobility in sending communities (i.e. 'cultures of migration'). An important role in sustaining migration was played by emerging migrant networks, which made it easier for new migrants to follow established migration routes, find jobs and get housing. These were to form the basis for what are now known as 'transnational communities' - groups of people who live across borders and have important affiliations in more than one society. (Portes et al., 1999; Vertovec, 2004). As migration became a long-term feature of relations between more and less-developed economies, it often changed in form. Most importantly, labour migration tended to lead on to family reunion and permanent settlement. Often this went against the objectives of labour-importing countries (Castles, 2004). Measures taken to restrict migration often had unexpected results: when Germany and France stopped recruitment from Turkey and Morocco in the 1970s, this led a shift from labour flows to family reunion and - in the case of Turkey and Germany - asylum seeker flows. Similarly, the effect of the militarisation of the US border since 1994 has been to turn sojourners into permanent settlers.

\section{Characteristics of migration}

This section summarises some main characteristics of the migratory flows and the migrants. More detail is to be found in the country studies.

\section{Volume}

Twenty to twenty-five million Indians are estimated to live outside the country - a large number but only about 2 per cent of India's huge population. The total includes overseas-born descendents of previous emigrants. Figures seem rather vague, but it is generally believed that there are over 10m Non-Resident Indians (NRIs - emigrants with Indian citizenship) as well as more than 10m Persons of Indian Origin (PIOs - 
first and subsequent generation persons of Indian origin, who have taken an overseas citizenship). The current annual outflow is put at about half a million.

The overwhelming majority of Mexican emigrants are in the USA, where they make up the world's largest diaspora - an estimated $26.6 \mathrm{~m}$ people of Mexican origin, of whom about $10 \mathrm{~m}$ were born in Mexico (nearly 10 per cent of Mexico's population). The diaspora includes people with Mexican citizenship, those with US citizenship and those with dual citizenship. The average annual Mexico-USA flow is put at 400,000 .

Morocco is North Africa's largest emigration country, with about $2.6 \mathrm{~m}$ migrants in Europe and $0.5 \mathrm{~m}$ elsewhere - equivalent to about 10 per cent of the country's population. The annual outflow is estimated at about $100,000 .^{3}$

The Philippines have about $8 \mathrm{~m}$ people abroad - again close to 10 per cent of the population. Nearly $1 \mathrm{~m}$ overseas contract workers (OCWs - i.e. temporary labour migrants) leave to work overseas each year.

Nearly $4 \mathrm{~m}$ people originating in Turkey live in Western Europe (of whom $2.5 \mathrm{~m}$ are in Germany). About $1.3 \mathrm{~m}$ people of Turkish origin are thought to have become European Union (EU) citizens - although many of these may have dual citizenship. (In terms of ethnicity, a sizeable though not precisely known proportion are of Kurdish background.) Other (mainly temporary) labour migrant groups are to be found in the Gulf states. Thus the equivalent of 5-6 per cent of the population of Turkey is emigrant. However, current outflows are fairly small and may well be exceeded by transit and immigration flows to Turkey.

\section{Types of migrant}

The great majority of emigrants from all five countries have been economic migrants, in search of better livelihoods. However, movement of refugees and asylum seekers has been important for Turkey - and remains so today with ethnic Kurds still seeking asylum. Recently, some Muslims have fled the southern Philippines as refugees, mostly to Malaysia.

\footnotetext{
${ }^{3}$ Personal communication from Hein de Haas, September 2005.
} 
Within the category of economic migrants there is considerable diversity. Highly-skilled Indians - engineers, IT specialists, scientists, managers, etc. - go mainly to the USA and other rich countries, while lower-skilled Indians go mainly to the Gulf. Many highly-skilled Filipinos find employment in the USA and Europe often experiencing occupational downgrading (e.g. from doctor to nurse) in the process. Filipina domestic workers often have quite high educational qualifications, which are wasted in their low-level jobs abroad. Filipinos with middle-level and technical skills find work in construction, processing industries and other sectors in the Gulf. However, most Filipino OCWs move to low-skilled jobs in a wide range of sectors, including seafaring. Most Mexican, Moroccan and Turkish migrants have been employed in relatively unqualified jobs. Since many Mexicans and Turks have vocational skills, this has often involved deskilling, particularly where movements take place in an irregular way, as between Mexico and the USA. More recently, there has been a trend towards more highly-skilled migration from all these countries although it is still relatively small compared with lower-skilled migration.

Family reunion makes up an increasing share of emigration. In Europe, unplanned settlement and family reunion from the 1970s led to a demographic normalisation of Turkish and Moroccan populations. Today, as the Turkish and Moroccan papers point out, much migration is for family formation rather than reunion, as second generation migrants of Turkish and Moroccan origin seek spouses in the ancestral homeland. In the Mexican case, the tightening of border control starting with Operation Gatekeeper in 1994 turned many undocumented temporary labour migrants into permanent settlers, who brought in their spouses and children. Most highly-skilled migrants move through special migration categories that give privileged rights to family reunion. This does not apply to the lower skilled, and most Indian and Filipino workers in the Gulf or the new Asian industrial countries have no chance of bringing in their families.

\section{Gender}

The Turkish and Moroccan guestworker migrations to Europe in the 1960s and 1970s were predominantly male, but there always also some women recruited as workers, for instance for clothing and food-processing industries. Similarly, most current 
Moroccan migration to Southern Europe and Indian Filipino migration to the Gulf is male-dominated. In all cases, though, female labour migration has grown, partly because of the increasing demand for labour in such female-dominated occupations as domestic work, nursing and other care, and entertainment. Some of the female migration takes the abusive form of trafficking for the sex industry. Philippines migration has become highly feminised, with women making up the majority of new labour migrants. For all the countries, family reunion movement of women and children has made a major contribution to normalising gender balances within migrant populations.

\section{Documented and undocumented migration}

Undocumented (also known as irregular or illegal) migration seems to be on the increase - due to the combination of tighter controls and continuing demand for labour in receiving countries. Most labour flows have started off through recruitment by governments, employers and agents - this applied to Turkish and Moroccan guestworkers, Indian and Filipino lower-skilled workers and even to Mexican braceros if one goes back far enough. In all these cases, except Asian labour migration to Gulf, abolition of legal recruitment systems by the governments of the USA and Western Europe led to enduring processes of undocumented migration. New migration flows from North Africa to Southern Europe have been mainly spontaneous and undocumented, often followed by legalisation through amnesties. Highly-skilled migration, on the other hand is mainly documented, due to international competition for scarce human capital.

\section{Situations in receiving countries}

Although mainly concerned with emigration and development, the country papers give some information on the situation of migrants in receiving countries. Highlyskilled Indian workers in western countries and the Gulf enjoy high living standards. This is sometimes matched by high social prestige, but not always, as Indian professionals may be subject to discrimination on grounds of national origins or race. 
It is hard to generalise about Filipinos, because of their broad diffusion and diversity. Women in particular experience exploitation and abuse in domestic work and similar sectors. Seafarers often have low wages and poor conditions. Moroccans in Europe are subject to low socio-economic status, poor conditions and social exclusion. On the other hand, they have become a significant economic and social factor in the Netherlands and France. The same applies to Mexicans in the USA.

The Turkish paper provides the most detail. It finds predominantly low socioeconomic status and high unemployment, as well as growing self-employment in the Netherlands and Germany. Education attainment is low on average, but with some trends to improvement for the second generation. Turks in Germany and the Netherlands experience high levels of residential segregation and social exclusion. Overall there is strong evidence of links between ethnicity and class, so that many Turks can be seen as part of a doubly-stigmatised lower social stratum. The practice of second generation immigrants seeking marriage partners in the country of origin seems to reinforce fears of 'non-integration' on the part of host populations. Such fears have been linked to new security concerns following Islamist terror attacks, though which all Muslims have come to be seen with suspicion by receiving states. ${ }^{4}$

\section{Migration transitions}

As Table 1 shows, four of the five emigration countries are not amongst the world's poorest. Mexico has reached the World Bank's 'upper middle' income group, while Turkey, Morocco and the Philippines are considered to be lower-middle income countries. Only India is considered a 'low income' country, but is not one of very poor countries with per capita incomes of less than US\$500 a year (most of which are in Sub-Saharan Africa). These are crude figures that say nothing about income

\footnotetext{
${ }^{4}$ More generally, there are signs of a general crisis of integration policies of all kinds in Europe: French assimilationist policies have given rise to high levels of segregation and exclusion of second generation youth, leading to the widespread riots of autumn 2005; British multiculturalism did not foster socio-economic equality for young people of South Asian origin nor prevent the alienation which was behind the bombings of 7 July 2007. The Netherlands has abandoned a long tradition of cultural tolerance to adopt draconian measures to control entries and force immigrants to conform to Dutch values. Sweden has both residential segregation and high unemployment of immigrants, despite its highly-developed welfare system.
} 
distribution (which is very uneven in all the countries), but they do reflect the fact that migrants come mainly from countries already caught up in a process of economic and social transformation.

\section{TABLE 1}

Gross NATIONAL INCOME (GNI) PER CAPITA 2005

\begin{tabular}{|l|c|c|c|}
\hline \multicolumn{1}{|c|}{ COUNTRY } & $\begin{array}{c}\text { RANK (OUT OF 208 } \\
\text { COUNTRIES AND } \\
\text { TERRITORIES) }\end{array}$ & $\begin{array}{c}\text { GNI PER CAPITA } \\
\text { IN US\$ }\end{array}$ & $\begin{array}{c}\text { WORLD BANK } \\
\text { INCOME GROUP }\end{array}$ \\
\hline Mexico & 71 & 7,310 & Upper-middle \\
\hline Turkey & 86 & 4,710 & Lower-middle \\
\hline Morocco & 129 & 1,730 & Lower-middle \\
\hline Philippines & 138 & 1,300 & Lower-middle \\
\hline India & 159 & 720 & Low \\
\hline
\end{tabular}

Source: (World Bank 2006c).

Note: This table is based on the World Bank's 'Atlas Methodology'. For explanations of this and the alternative 'Purchasing Power Methodology' see the source document.

Migration has been both a result of such changes and a cause of them. Social scientists have developed the notion of a 'migration transition' to analyse such shifts (Zelinsky, 1971). ${ }^{5}$ According to this theory, at the beginning of the process of modernisation and industrialisation, there is frequently an increase in emigration, due to population growth, a decline in rural employment and low wage levels. This was the case in early nineteenth-century Britain, just as it was in late nineteenth-century Japan, or Korea in the 1970s. As industrialisation proceeds, labour supply declines and domestic wage levels rise; as a result emigration falls and labour immigration begins to take its place. Thus industrialising countries tend to move through an initial stage of emigration, followed by a stage of both in-and outflows, until finally there is

\footnotetext{
${ }^{5}$ See also IMI working paper 2007-6 on Morocco by Hein de Haas.
} 
a transition to being predominantly a country of immigration (Martin et al., 1996, 171-2). A more recent concept used to describe this pattern is the 'migration hump': a chart of emigration shows a rising line as economic growth takes off, then a flattening curve, followed in the long run by a decline, as a mature industrial economy emerges (Martin and Taylor, 2001).

The evidence of our five case studies casts doubts on the validity of such general theories of evolutionary stages. In reality, changes seem to take more complex paths and to have uneven effects on different sectors. In India economic change shows a marked dualism: the emergence of a high technology sector seems to have had little effect on the impoverished rural majority is still not experiencing broad-based economic development. Emigration is too low relative to population to have marked effects. India does have limited immigration, both of low- and semi-skilled migrants, and of refugees from Nepal, Tibet and Bangladesh, but cumulating in numbers that have often caused social and political concerns. The Philippines too, in the absence of rapid and sustained economic development, remains predominantly an emigration country. The Mexican experience shows that mass labour emigration may not necessarily contribute to economic development of the country of origin at all. Both remittances and growth of the maquila industry seem to do more to deepen Mexican dependency on the USA than to bring about genuine development.Mexico has increasing transit migration mainly of Central Americans and Caribbeans seeking to enter the USA via Mexico. Some of them are staying on in Mexico, but emigration remains the dominant type of flow, and it seems too early to speak of a migration transition.

Morocco is experiencing a change in migration patterns. This reflects improvements in economic performance and governance. Emigration remains high, but transit migration of sub-Saharan Africans seeking to enter Europe has grown rapidly. Many transit migrant become stranded: unsuccessful in their attempts to get to Spain or Italy and unable to return home, they remain in Morocco. In addition an increasing number of sub-Saharan migrants are interested in seeking opportunities in North Africa (for instance in Libya, Eygpt or Morocco itself). Sub-Saharan migrants who remain in Morocco are considered illegal residents by the authorities and their economic situation is often very poor - although some manage to find niches in the informal economy. However, economic development is still at an early stage, and the 
number of long-term immigrants is still too small to come to definite conclusions about an impending migration transition.

Turkey seems to come closest to the model of the migration transition. Emigration has declined sharply, transit migration - both economic and forced - has increased, and Turkey has become a destination for economic migrants from Eastern European and former Soviet countries (including Moldova, Georgia, Armenia and Bulgaria). However, there is no evidence that migration itself has been a driving factor in this shift. Indeed the failure of attempts to harness migrant remittances and investments for industrial growth in the 1970s and 1980s shows the limitations of ideas on remittance-led development. The causality seems to be the other way round. Political reform institutional modernisation, demographic shifts and social change have created the conditions for economic growth. Rather than a migration transition, there seems to be a process of internally-generated development, which has reduced the pressures for emigration

\section{The state and emigration}

The country studies all paid considerable attention to the role of the states of the countries of origin. They asked such questions as: to what extent has emigration been state-led? And how much do states do today to manage emigration and to protect their citizens abroad? In comparing these findings it is important to remember that one aspect of under-development is the limited autonomy of southern states towards more powerful northern counterparts. This is shown at a general level through the imposition of structural adjustment polices on many southern states, and more specifically in the migration field though the limited power of southern states to regulate migration due to the surplus supply of lower-skilled workers on world labour markets. 


\section{Emigration policies}

In four of the five countries, the state played a key role in initiating labour export: Morocco and Turkey worked with the authorities of receiving countries in the 1960s and 1970s to organise recruitment, select workers and often to ensure political control. The motivations were to export both unemployment and political dissent, and to secure remittances and skills for future development. The Philippines Government under President Marcos also initiated a policy of labour export for similar reasons, although perhaps more with the objective of compensating for lack of development at home than bringing it about. The Mexican state worked with its US counterpart in running the bracero programme. When this was unilaterally stopped by the US Government, Mexico, according to the country study, moved to 'a policy of no policy', which meant looking on as undocumented migration grew. India by contrast had no overseas employment policy at the start of recent emigration.

More recently, all the states seem to have shifted towards what the Indian paper calls a 'developmental paradigm'. This means emphasising the benefits of remittances and other hoped-for effects of migration, like skills transfer, and seeking ways to maximise them. Where emigration is very large, it can come to be seen a key factor in the national economy. In the case of Mexico, this has taken the form of the policy of 'remittance-led development', in which labour export has become the core of a strategy for 'national development' which has in fact led to greater dependency. The Philippine Government too sees labour export a crucial and enduring aspect of economic policy, and seeks to maximise it. The result of thirty years of systematic labour export seems to be an absence of industrialization and economic growth, which is particularly striking in view of the much more positive experience of fairly similar Southeast Asian economies, like those of Malaysia and Thailand.

\section{Institutions}

With perceptions of the growing national importance of emigration, states have introduced institutions to manage it. In 2004 India set up a Ministry of Overseas Indian Affairs (MOIA), which incorporated the long-standing Protectorate of Emigrants. An Overseas Indian Workers Welfare Fund was established, while the 
Education Department reserved university places and scholarships for PIOs and NRIs. Mexico set up an Institute of Mexicans Abroad within its Department of Foreign Affairs, designed to strengthen emigrants' ties to their homeland, as well as to support education and health programmes.

Up to the 1980s, the Moroccan Government was mainly concerned with maintaining political control over its workers abroad, for instance by keeping them away from left-wing trade unions. The Moroccan consulates worked with the secret service to set up migrant associations known as amicales. Policies changed in 1990 with the establishment of a Ministry for Moroccans Abroad (incorporated in 1997 into the Ministry of Foreign Affairs). The Fondation Hassan II was set up to support cultural and social activities among migrants, while the Banque Al Amal was to encourage migrant investments and economic projects. Turkey's Diyanet, a government institution responsible for religious affairs, supported religious associations in Germany and the Netherlands. The Turkish Ministry of Labour and Social Security set up a Directorate General of External Relations and Services for Workers Abroad.

The Philippine Government devised a comprehensive institutional structure to manage emigration. The Overseas Workers Welfare Administration (OWWA) was set up in 1977 to foster the welfare of migrants and their families left at home. A Commission on Filipinos Overseas (CFO) was established in 1980 to promote the interests and well-being of emigrants - it was transferred from Foreign Affairs to the Office of the President in 2004. Its purpose is to nurture the ties between emigrants and the Philippines. A third major institution is the Philippine Overseas Employment Administration (POEA) within the Department of Labour, which recruits and selects OCWs, as well as processing their documents and contracts, and providing premigration orientation courses. It is also responsible for licensing and regulating recruitment and placement agencies.

\section{Protecting citizens in transit and overseas}

Highly-skilled workers often need little special protection, since possession of human capital gives them bargaining power in international labour markets, as well as access to professional legal services. The situation is very different for lower-skilled 
workers: a global surplus of jobseekers puts the market power in the hands of the governments and employers of the labour-importing countries. Nonetheless, sendingcountry governments do take measures to try to protect their citizens abroad - often in response to pressure from migrant associations and other civil society organisations. For instance the Migrant Workers and Overseas Filipino Act of 1995 was a direct result of political mobilisation at the time of the Flor Contemplacion case. This law, designed to protect Filipinos abroad, is summarised by Assis (Assis 2006). Other sending countries have also introduced legal measures, such as registration and regulation of agents (as in India) and steps to prevent trafficking and exploitation of women and children. Mexico has set up a service called Grupo Beta to protect migrants - even undocumented ones - from criminal activities when they try to cross the border; this includes rescue activities in cooperation with police on both sides of the border. Mexico also has a Programa Paisano to 'alleviate the abusive treatment, extortion, robbery or other forms of corruption committed by public authorities when Mexican migrants return to their nation' (Delgado Wise and Covarrubias 2006).

The most difficult problem for sending states is establishing effective arrangements to protect workers abroad. This is generally the task of foreign affairs departments, which appoint labour attaches and welfare officers at their consulates in labour-importing countries. However, their ability to assist workers in dispute with employers or otherwise in difficulties is limited by the frequent unwillingness of the authorities of receiving countries to cooperate. Further constraints include shortage of resources, lack of training, and social distance and lack of trust between officials and migrant workers.

\section{International legal instruments}

In the guestworker period, a series of bilateral agreements were concluded between labour-recruiting and supplying states: e.g. Germany and the Netherlands with Turkey and Morocco. These agreements regulated recruitment, employment conditions and social security entitlements. Although they were often rather restrictive of worker rights, they did provide a legal residential and employment status and some protection to workers. Such agreements were unilaterally terminated by the receiving states in 1973-4. In more recent waves of labour migration, receiving states have on the whole 
been unwilling to conclude such agreements, apparently because they saw no need to make concessions to migrant workers and their countries of origin on rights and entitlements. ${ }^{6}$

Attempts have also been made to introduce international legal instruments to safeguard the rights of migrant workers. The most important are International Labour Organisation (ILO) Conventions No. 97 of 1949 and No. 143 of 1975, and the United Nations Convention on the Rights of Migrant Workers and Members of their Families of 1990. These instruments could do a great deal to improve the situation of migrants at every stage if the migratory process - if states were willing to sign and implement them. Unfortunately, that is not the case. The most important instrument, the 1990 United Nations Convention, did not come into force until 2003, because few states were willing to ratify it. Even today, only 34 states have signed up - almost exclusively emigration countries. The reluctance to move towards global governance of migration is essentially due to the fear of labour-recruiting countries that regulation will increase the costs of migrant labour and put social obligations on receiving countries.

\section{Recognising the diaspora}

With growing understanding of the potential economic contribution of emigrants, governmental and public attitudes have changed. In the past, emigrants were often seen as deserting their home country by going to work elsewhere. Now they have been redefined as 'angels of development' (India) or bagung bayani, the country's new heroes (Philippines). The Moroccan Government now speaks of 'Moroccan Residents Abroad' and sets out to court the diaspora. Indian migrants and their descendants are seen as 'transnational or global Indian citizens'. The Turkish Government appointed a Parliamentary Commission to report on Turks abroad in 2003, and now argues that integration into host societies is not incompatible with Turkish national identity. During German Chancellor Angela Merkel's visit to Turkey

\footnotetext{
${ }^{6}$ There are some exceptions to this, which cannot be discussed in detail here. The most significant are the rather limited temporary migrant labour programmes introduced in Germany since the early 1990s (see Castles, 2006).
} 
in 2006, the Turkish Prime Minister Tayyip Erdogan re-iterated his strong support for the integration of Turkish immigrants into their host societies. Philippine measures to enhance the symbolic recognition of emigrants include presidential visits to communities overseas, the celebration of 'migrant worker days', the introduction of the Balikbayan status to provide special rights (e.g. funds transfer, import of goods, reduction of import duties) for overseas Filipinos, and a 'Miss Overseas Philippines' beauty contest open to young women of Philippine origin - even if they are no longer citizens (see Asis in this volume and Aguilar, 1999). It is unclear how migrants themselves see this sudden enhancement in prestige. In the past, many migrants have been quite mistrustful of the state, especially where authoritarian regimes have sought to control their political and trade union activities. The growing cooperation between migrant associations and states (see below) is indicative of change on both sides.

\section{Rights for citizens overseas}

The most significant way to recognise the diaspora is to include them in domestic political processes through permitting dual citizenship and allowing nationals abroad to vote. All five countries show trends in these directions. In 2006 India introduced the right to dual citizenship for PIOs in all countries except Pakistan and Bangladesh (this is due to historical reasons connected with Partition of India after 1947). Voting rights for Indians abroad were also introduced. Khadria (2006) notes that dual citizenship is mainly relevant for highly-skilled emigrants in the USA, Canada, Australia or the UK, who take on the citizenship of those countries, while overseas voting rights are most significant for lower-skilled Indian workers in the Gulf.

Mexico introduced dual nationality for Mexicans abroad in 1996, but this did not encompass voting rights. Such rights were introduced for presidential elections in 2005 , with provisions for postal voting from abroad. However it seems that relatively few of the estimated 4.5 million potential voters actually registered for the 2006 Presidential Election. This may have made a significant difference, but it is not clear whether the lack of voter registration was due to bureaucratic obstacles or other factors. The King of Morocco announced in 2005 that migrants would henceforth be allowed to vote and to be elected to parliament, and that a Council of Moroccans 
Abroad would be established to advise the Government. The Philippine Government introduced both dual citizenship and to the right to vote for Filipinos abroad in 2003.

The case of Turkey is more complicated, due to the concentration of emigrants in Germany, a receiving state still unwilling to accept dual citizenship. A 1981 amendment to Turkish Nationality Law permitted dual citizenship, but most Turks abroad could not take advantage of this, due to restrictions in Germany. In response, there were further changes to Nationality Law in 1995: a 'pink card' was introduced to confer 'privileged non-citizen status' on former Turks abroad; this includes rights to own property and run businesses in Turkey - but not to vote.

\section{Migrant associations}

In the context of state efforts to recognise diasporas and to enhance their participation in national development, migrant associations take on a new importance. Their roles can vary, depending on the circumstances:

- To support and assist migrants both during emigration and on return;

- To mobilise migrants to campaign for improvements in their rights and conditions, and against repressive or discriminatory measures;

- To work with states to enhance the contribution of diasporas and returnees to development.

In the five country studies, the emphasis was mainly on the last of these three roles, although the others were not ignored. The Indian paper described the proliferation of associations, especially among highly-skilled migrants in the USA. Indian associations overseas are based on criteria of region, language, caste and religion. There are also occupation-specific associations for professionals and students that support development efforts, as well as umbrella organisations that seek to link all the others together. Khadria (in this volume) notes over 1000 US-based Indian associations, some with branches in Canada as well. Similar associations are to be 
found in Europe and the Gulf. Certain associations set up and run schools for the children of Indian migrants.

Mexican associations are very strong in the USA. Many are based on regional or linguistic links, while others are linked to trade unions or religious groupings. Of special importance are the hometown associations, which come together for social and cultural reasons and mutual aid, but have also become important development actors by collecting money to invest in community projects in the hometown. Delgado Wise and Covarrubias (in this volume) speak of a 'new social subject: the collective migrant'. They note the existence of 623 hometown associations covering 9 per cent of emigrants. They also draw attention to the lively Mexican media in the USA, with 300 radio stations, 700 newspapers and many TV stations. These associations and media organisations played an important part in the unprecedented mobilisation of Mexican migrants in the USA in early 2006 against proposals for legislation designed to reduce migrant rights and further militarise the US-Mexico border.

Moroccan migrant associations have grown significantly in recent years, reflecting the general trend towards political liberalisation and the emergence of a stronger civil society. Avci and Kirisci (in this volume) point to the recent expansion of Moroccan associations in the Netherlands, where there is now one Moroccan association for every 462 Moroccan-origin people. Migrations et Développement associations are increasingly significant in France and Morocco, and now receive financial support from the Moroccan Government.

The Philippines has a strong civil society sector, with many non-governmental organisations linked to the Church, to trade unions and to political parties. Advocacy groups concerned with migration appear to have significant influence on the Philippine state, while associations concerned with welfare, migrant rights and women' issues are important in countries with Filipino migrant populations.

Turkish migrant associations are numerous, but also very diverse, reflecting political, religious, generational and social divisions in Turkey and within migrant populations. Avci and Kirisci (in this volume) point out that Turkish associations may have very different attitudes on religious and political matters concerning the homeland), yet work together on issues connected with conditions or policies in the host country. In the Netherlands, there is one association for every 291 Turkish residents, while Turkish newspapers and television also have a strong presence. The strength of Turkish groups appears to be partly due to host government policies that 
support minority associations. On the other hand, host populations sometimes see migrant associations as a sign of non-integration.

\section{Migration and development}

Recent international (GCIM 2005) and national (IDC 2004) reports stress the potential benefits of migration for development, laying special stress on the role of economic remittances in improving livelihoods, increasing demand and stimulating production (Carling, 2006). ${ }^{7}$ Other major development benefits are thought to lie in technology transfer and the return of the highly skilled, and 'social remittances' - the transmission of knowledge and development-friendly attitudes to countries of origin by migrants and returnees. The most recent debates on the development benefits of migration focus on the role of diasporas as potential partners for development. The five country studies examine these issues, pointing to positive development effects of migration, but also to potential negative effects.

\section{Economic remittances}

The transfer home of migrant earnings and savings is generally seen as the most important positive effect of migration for the countries of origin. According to the World Bank's review of 2004 data, India was the world's top remittance receiver, followed by China and then Mexico. Philippines ranked fifth and Morocco tenth, while Turkey was not amongst the top twenty receivers (World Bank 2006a, 90).

\footnotetext{
${ }^{7}$ Further important initiatives in this area include the meeting of high officials from 57 African and European States in Rabat in July 2006, which was concerned with finding policies to enhance migration management, though a combination of tighter border control and development assistance (Noll, 2006); and the UN General Assembly High Level Dialogue on Migration and Development in New York in September 2006 (see http://www.un.org/esa/population/hldmigration/)
} 
TABLE 2

Remittances and Gross Domestic Product (GDP) 2004

\begin{tabular}{|l|c|c|c|}
\hline \multicolumn{1}{|c|}{ COUNTRY } & $\begin{array}{c}\text { REMITTANCES: } \\
\text { US\$ BILLIONS }\end{array}$ & $\begin{array}{c}\text { TOTAL GDP } \\
\text { US\$ BILLIONS }\end{array}$ & $\begin{array}{c}\text { REMITTANCES AS } \\
\text { PERCENTAGE OF } \\
\text { GDP }\end{array}$ \\
\hline India & 21.7 & 695 & 3.1 \\
\hline Mexico & 18.1 & 683 & 2.7 \\
\hline Philippines & 11.6 & 90 & 11.8 \\
\hline Morocco & 4.2 & 50 & 8.1 \\
\hline Turkey & 1.7 & 240 & 0.5 \\
\hline
\end{tabular}

Note: All data is for 2004, except for Turkey, for which both remittances and GDP are 2003.

Sources: For remittances: (World Bank 2006a) except for the Turkish figure which is for 2003 and comes from Gamze and Kirisci (in this volume); GDP: (World Bank 2006b).

As Table 2 shows, remittances make a very large relative contribution to GDP in the Philippines (11.8 per cent) and Morocco (8.1 per cent). For India and Mexico, remittances account for a smaller share but still significant share of GDP, while for Turkey the share is quite small. The country studies draw attention to the significance of remittances, but also to problems they sometimes bring. In the case of India, remittances make an important contribution to the balance of payments. In areas of migrant origin, they are a major factor in poverty reduction. For instance, remittances make up 10 per cent of GDP in Kerala (Khadria in this volume). But remittances do not necessarily contribute to development: they can lead to ostentatious consumption and actually drain development potential. Moreover, Khadria draws attention to important knowledge gaps on the development effects of remittances.

In Mexico too, remittances have grown rapidly and are an important contributor to the balance of payments. They have become vital for economic and social stability, by mitigating poverty. Delgado Wise and Covarrubias (in this volume) argue that the migration relationship has become an important mechanism that reinforces Mexican economic dependency on the USA; they see the remittance 
led-model as a 'perversion of the idea of development that offers no prospects for the future'. Mexican labour export to the USA - both directly through migration and indirectly through the maquila industry - is important for the re-structuring of the US economy, but only increases Mexican dependency, without contributing to positive economic and social change at home.

The Moroccan study also points to the important role of remittances for the balance of payments and for poverty alleviation, and notes that remittances are primarily used for consumption rather than investment. However, De Haas (in this volume) argues that remittance-driven consumption expenditure and 'non-productive' investments in housing, health and education have created substantial employment among non-migrants and may, therefore, be an indirect form of productive investment. In addition, the growth of tourism, which is important for the Moroccan economy, is partly linked to the temporary or permanent return of migrants.

Remittances to Turkey have declined from a peak of US\$5.4bn in 1998 (which covered 37 per cent of Turkey's trade deficit), to US\$1.7bn in 2003 (equivalent to 8 per cent of the trade deficit). The decline has probably continued since, and is due to falling emigration and the permanent settlement of earlier migrants in Western Europe. This is not surprising in view of Turkey's migration transition, mentioned above. In the last forty years, remittances have improved incomes in emigration regions, but past government attempts to use them for industrial investment have largely failed.

\section{Social remittances}

Social remittances are defined by Peggy Levitt as 'the ideas, behaviours, identities and social capital that flow from receiving- to sending-country communities' (Levitt, 1998, 926). Positive expectations by analysts and policy-makers of the impact of social remittances have their roots in the modernisation theories of the 1950s, which argued that the transfer of 'western values' of rationality, individualism and entrepreneurship were crucial for development. However, critical assessments, like those of Levitt and our country studies, show that social remittances can have ambiguous consequences. If optimistic stories come back to the home community about the low risks and considerable benefits of moving to higher-wage economies, 
this can encourage more people to move. This leads to the development of a 'culture of emigration' in which spending a time working abroad becomes a normal 'rite of passage' for young people. The case studies of Mexico, Morocco and the Philippines refer to this phenomenon. The other side of the picture is the effects on the community of origin. The Indian, Moroccan and Turkish studies all mention that migration has been a force for change in sending areas, through the transfer of attitudes conducive to change and development. On the other hand, the absence of young men and women in their most productive years can have negative effects on social change and economic growth. The Moroccan study draws attention to the transfer of skills through returning migrants. Of course, as the Turkish study points out, where migrants settle in receiving areas or only return at the end of their working lives, this effect is reduced.

\section{Mobilising the diaspora for development}

The idea that governments and international agencies should work with diasporas, and find ways of reinforcing their development capacities and attitudes has received a lot of attention recently (see GCIM 2005; IDC 2004). All the sending country governments have taken measures to achieve these aims.

The Indian Ministry for Indians Overseas supports the Diaspora Knowledge Network, which is designed to connect highly-skilled emigrants with opportunities at home. Mexico has set up a mechanism to encourage migrant collective investments in community projects. The Programa Tres por Uno (Three-for-One Programme) was established in 1999, based on regional programmes set up since the early 1990s. Tres por Uno is administered by the government's Secretariat for Social Development (SEDESOL). ${ }^{8}$ Transfers from Mexican hometown associations are matched by equal commitments from municipal, state and federal authorities. Funds are used for projects to improve roads, drinking water, sewage and electricity. In 2004, more than US\$50m were made available in this way. There is also an 'Invest in Mexico' programme of the Inter-American Development Bank and Nacional Financiera.

\footnotetext{
${ }^{8}$ See http://www.sedesol.gob.mx/subsecretarias/desarrollosocial/programasdesarrollosocial.htm
} 
Morocco set up the Banque Al Amal in 1989, to encourage legal transfer of remittances and to support migrants' projects. In the Philippines, the Commission for Filipinos Overseas (CFO) supports LINKAPIL (Link for Philippine Development) to mobilise the resources of the diaspora.

Here too Turkey is something of an exception. After the failure of attempts to channel migrant worker remittances into industrial investments in the 1970s (Hönekopp and Tayanç, 1998; Martin 1991), the Turkish Government now seems to concentrate on symbolic and political aspects. The diaspora is mainly seen in terms of maintaining national identity. The mechanism for this is state support for religious, cultural and social activities. Again this difference seems to be linked to the stage of the migration transition that has been reached by Turkey. In addition, the EU dimension has become important: Turkish politicians including the Prime Minister have said that migrants can act as a bridge between Turkey and the EU. The Prime Minister has repeatedly called on Turkish immigrants to integrate and to vote and stand for election in local elections.

\section{Differences, similarities and convergence}

It is now possible to return to the questions posed at the beginning this paper. The first objective of the paper was to see if the five major emigration countries shared significant common characteristics so that analysts, policy-makers and practitioners could gain insights from the comparison. One way of answering this is by summarising the differences and similarities in the emigration experience of the five countries, and then discussing the extent of convergence in outcomes, responses and policies at present.

\section{The forces driving migration}

Although their population size varies considerably, all the countries share the characteristic of a late demographic transition, which means that they have growing 
and relatively young populations. Their economies have not grown fast enough to absorb the many young labour market entrants. This is the result of blocked or uneven economic development, which in turn can be linked to past colonial domination and more recently to economic domination by multi-national corporations, northern states and international financial institutions. With regard to political factors, the Moroccan and Philippine governments used labour emigration as a way of getting rid of ethnic minorities or political dissidents. In the case of Turkey, many ethnic and political activists sought protection from persecution by fleeing the country. On the other hand, once legal labour migration was stopped, some migrants claimed asylum as a way of avoiding entry restrictions. In more recent years India, Morocco and Turkey have gone a fair way towards shaking off post-colonial economic domination, while the Philippines has made much more limited progress and Mexico apparently very little. In the Philippines, the key problem seems to be the inability to carry out essential economic reforms - such as land reform to bring about greater equity in rural areas which in turn seems to be linked to problems of democratic participation and political stability. For Mexico, the regional context - the domination by a very powerful neighbour - remains crucial.

\section{Migration and social transformation}

Despite differences in geographical situation and historical experiences, there are strong similarities in the political economy of emigration. This is why it is important to analyse migration as part of the process of global social transformation that started with European colonial expansion in the $16^{\text {th }}$ century. Mobilisation of the labour power of Africa, Asia and Latin America has always been part of this process, whether in the form of slavery, indentured labour or forced labour. Globalisation, as the latest stage of social transformation, involves large-scale migration to meet the economic and - increasingly - demographic demands of northern economies. This can involve integration into regional labour markets (in the case of Mexico, Morocco and Turkey) or global labour markets (India and Philippines). In both cases, a key characteristic is differentiation of workers though immigration rules and categories according to human capital, skills and national or ethnic origins. A crucial aspect of 
economic globalisation is the use of subordinate categories of labour - especially migrant workers, both regular and irregular - to facilitate the casualisation and deregulation of employment. This process of 'precarization of labour markets' works both at the national level, through the erosion of labour conditions in Europe and North America, and internationally through competition from new industrial economies with relatively low wages and poor working conditions.

\section{Migration history}

What makes a country into a labour reservoir for the developed countries? The comparison of India, Mexico, Morocco and the Philippines showed that this was the culmination of long historical processes, especially in the colonial period. Turkey was rather different, since labour emigration did not start until the 1960s, as a result of cooperation between the German, Dutch and the Turkish states. However, complementarity between economic and political motivations of elites in sending and receiving countries seems to be a frequent feature at the inception of labour migration. Similarly, we find convergence in longer-term patterns: once migratory movements start, they tend to become self-sustaining, even if government policies change. This is due not only to employer demand, but also to the development of migrant networks, which support family reunion and settlement. In addition, long-term patterns of dependency emerge, where remittances become a crucial part of local economies, so that migration becomes a normal part of the life-cycle for each new generation..

\section{Characteristics of migration}

Migration patterns have varied considerably with regard to volume, timing, the relative importance of economic and forced migration, gender patterns and skills distribution. Emigration has been very large relative to population for Mexico, Morocco and Philippines - around 10 per cent in each case. All five countries have become providers of labour for the rich economies of North America and Europe, and, more recently the emerging industrial economies of East and Southeast Asia and the Gulf oil states. With regard to skill levels, Indian migration seems to fall into two large groups: highly-skilled migrants in the USA, other developed countries and (to a 
lesser extent) the Gulf, and lower-skilled workers mainly in the Gulf. Filipino migrants show a wide range of skill levels, while Mexicans, Moroccans and Turks are concentrated in lower-skill occupations. Recently, some highly-skilled Moroccans have migrated to the USA, a trend which applies to Mexicans and Turks as well.

States differentiate between migrants, competing for the highly-skilled, while trying to reduce entries of lower-skilled workers. This is reflected in living conditions and standards. Highly-skilled workers generally enjoy good salaries and conditions (even though they may experience some discrimination and racism). Lower-skilled migrant workers and their families have disadvantaged economic, social and political positions in receiving societies. Often this is compounded by the denial of a range of rights - even to legal guestworkers or OCWs. Undocumented workers are much worse off: denied official permission to enter and work, they can easily be exploited by employers.

Gender balances have become more equal, with increasing numbers of women migrating both as workers and as spouses. Age distributions have also broadened, with more children and older people among migrant populations. This demographic normalisation is linked to the general trend towards long-term or permanent settlement. Migration for family formation has emerged amongst second-generation groups. Government policies affect migration patterns - often in unexpected ways. Stopping guestworker recruitment (in Europe) and the militarisation of the USMexico border led to more undocumented migration and increased settlement in the receiving countries - exactly the opposite of the policy aims.

\section{Migration transitions}

According to the theory of the migration transition, emigration increases in the early stages of development, and only declines as a result of long-term demographic and economic changes. As our five case studies show, migration and development are linked in varying ways. Often it is development processes driven by internal economic, social and political factors that change the conditions and forms of migration. The estimated $20-25 \mathrm{~m}$ Indians outside their country are equivalent to about 2 per cent of total population, and this volume seems too low to contribute to a migration transition. The Philippines has very large emigration but in the absence of 
other factors needed for sustainable economic development, there are no signs of a migration transition. In Mexico, we can see some elements of transition, with increased transit migration and some settlement of immigrants, but economic dependency is still very strong. Morocco may be on the verge of a migration transition, while this trend seems quite advanced in Turkey - driven by important changes in infrastructure and institutions.

\section{The state and emigration}

In the cases of Mexico, Morocco, Philippines and Turkey, the state played a key role in starting labour migration - often in cooperation with receiving country authorities. Some states saw emigration as a potential instrument for development, but others were more concerned with exporting unemployment and political dissent. Later, emigration country states shifted towards a developmental paradigm, emphasising the benefits of remittances, technology transfer, and 'brain circulation'. They also developed institutions to regulate recruiters and agencies, prevent trafficking and smuggling, prepare migrants, and protect them while overseas. The scope and capacity of such institutions varies considerably - the Philippines have gone furthest in developing a comprehensive set of legislation and agencies. The effectiveness of measures to protect migrants is dubious, since emigration country authorities lack not only resources but also the power to demand improvements from receiving countries at a time of global over-supply of lower-skilled workers.

A key convergence lies in the attitude of country of origin states to their nationals abroad. At the inception of labour migration, emigrants were often seen as 'surplus population' or 'troublemakers' to be got rid off. While abroad they were regarded as potential threats to the homeland. The Turkish and Moroccan states sought control through political surveillance and support for patriotic or religious organisations. Since the 1980s, there has been a general shift. Citizens abroad are now seen as valuable diasporas, which can contribute to development, maintain national identity and support the economic and political interests of the former homeland. Migrants have been redefined as 'heroes of development', and governments support political and cultural associations, development banks and networks designed to involve the diaspora in development efforts. All five countries have introduced 
legislation to allow dual citizenship (or nationality) for nationals abroad, and to provide them with voting rights in the country of origin.

\section{Migrant associations}

Recognising the diaspora means working with migrant associations. Here too there is diversity in membership size and composition, political and religious affiliations, objectives and modes of organisation. An important convergence lies in the increasing strength of migrant associations in receiving countries. This has made them a significant factor in both receiving country and origin county politics. Another convergence lies in their willingness - at times - to work across social, political and religious divisions to represent the interests of co-ethnics (or even all migrants) in confrontations with receiving country institutions or political groupings. However, mass mobilisations like that of Mexicans against planned anti-immigrant legislation in the USA in early 2006 only arise in exceptional circumstances. A third convergence lies in the increasing involvement of migrant associations in development initiatives for their homelands.

\section{Conclusion: can migration be an instrument for development?}

The previous section addressed the first objective of the country studies by summarising the migration experience of the five major emigration countries. The comparison revealed important differences in the societal and historical contexts, migration patterns and policy approaches of the five countries, yet also showed many similarities and - most significantly - convergence in important areas. A second objective of the country studies was to examine the extent to which migration does in fact contribute to development.

As pointed out above, the most important development benefit of migration is generally perceived to be the role of economic remittances in improving livelihoods, 
increasing demand and stimulating production. Other major development benefits are seen in technology transfer and the return of the highly skilled, and in 'social remittances' (transfer of new knowledge and attitudes by diasporas and returnees). The most recent debates on the development benefits of migration focus on the role of diasporas as potential partners for development.

It is important to question the notion of development, by asking such questions as 'what type of development' and 'development for whom'? It is debatable whether the term development - which is usually used in a very affirmative and vague manner - is really very useful in this area. It was suggested above that an analysis in terms of social transformation might lead to more useful results. What could this mean for our comparison of the experience of change linked to migration in the five case-study countries?

With regard to economic remittances, the country studies showed a diversity of experiences within and between countries of origin. The general lesson from the comparison was that remittances do not automatically lead to economic and social changes of benefit to the population of emigration countries. Indeed, under certain circumstances, remittances can lead to conspicuous consumption, inefficient types of investment and economic dependence on continuing emigration, and sometimes even hide a reverse flow of funds to rich countries. The claimed positive link between remittances and economic growth only applies if appropriate policies are put in place to encourage legal transfers and productive investment, to reduce corruption and unnecessary bureaucracy, and to provide an investment-friendly infrastructure. The experience with technology transfer and return of the highly skilled is rather similar: positive effects are only realised if opportunities and structures in emigration countries change in such a way that emigrants do return before the end of their working lives. A further pre-condition is that skilled migrants are able to enhance or at least maintain their qualifications while away. This is often not the case, since skilled migrants may be employed in low-skilled jobs.

Social remittances can also have varying effects. The message coming back to home communities from emigrants can be that new ways of working, investing and running public affairs can bring prosperity, but it can also be that emigration is the only way out of a hopeless situation. The emergence of emigration as a normal 'rite of passage' for young people can lead to a loss not only of productive workers, but also to the absence of agents of change. The social and economic costs of emigration can 
be high: the country studies draw attention to the distress caused by long-term separation of families (such as the 'Gulf wives syndrome' in India); the distortion of education systems re-shaped to meet the needs of destination countries (mentioned in the papers on India and the Philippines); the risks and dangers encountered by migrants; the potential loss of skills and human resources that can block development (mentioned for Mexico, Philippines and Turkey); and the 'de-accumulation of Mexican wealth' and its transfer to the USA. Overall, emigration of labour - whether skilled or less skilled - can lead to serious loss of potential growth for the country of emigration. The question is whether this loss can be outweighed in the long run by positive effects.

Recognition of the role of diasporas in development does seem an important step forward. This new discourse in the international migration field follows changes of perceptions in emigration countries and the introduction of a range of measures and institutions to involve the diaspora in bringing about positive changes in the homeland. Although all the country studies describe such efforts, there is insufficient data and research evidence to assess their success. Collective remittances for community investment by hometown associations and similar groups are still very small in comparison with private flows. Knowledge transfer networks (like India's Diaspora Knowledge Network or the Philippine's LINKAPIL) seem positive, but quite small compared with individual remittances and commercial transfers.

The general conclusion on migration and social transformation is therefore that there is a need for broadly-based long-term approaches that links the potential benefits of migration with more general strategies to reduce inequality and to improve economic infrastructure, social welfare and political governance. If such strategies are adopted, there is a good chance of outcomes beneficial to sending country populations, but the conditions for realising these are complex and difficult. Strategies of 'remittance-led development' seem simplistic and naïve. Migration alone cannot remove structural constraints to economic growth, social change and greater democracy.

In the Mexican case this would mean rejecting the asymmetric integration of the Mexican economy and labour market into the USA sphere of control. For Morocco and Turkey it would mean recognising the processes through which former labour exporters can become countries of transit and immigration, and refusing to take on the role of 'buffer state' or 'dumping ground' for asylum seekers or migrants 
refused entry into the EU. For the Philippines it would mean abandoning the idea of being the 'producer of workers for the world', which implies acceptance of permanent subordination in the international division of labour. Instead there need to be policies that combine political and economic reform at home with recognition of the potential role of the diaspora and returnees. India is rather different here, in that migration makes a smaller relative contribution to change. All the same remittances and return of highly-skilled personnel are significant, and need to be better linked to wider economic goals.

What does mean for South-South cooperation? A central aim of the workshop was to explore common ground between emigration countries as a basis for suggesting strategies for South-South cooperation across boundaries. This theme was not explored in detail in the country studies, and will not be here. By examining the experiences of five important emigration countries, and by establishing the important similarities and convergences between them, the country studies and this comparative paper were designed to provide a basis for developing strategies and mechanisms for working together. This was pursued in the further debates at Bellagio, and is reflected in the final document: Perspectives from the South: Conclusions on Migration and Development. 


\section{References}

AdEPOJU, A., (2006), 'Leading issues in international migration in sub-Saharan Africa' in Cross, C., Gelderblom, D., Roux, N. and Mafukidze, J. (eds.) Views on Migration in Sub-Saharan Africa. Cape Town: HSRC Press.

Aguilar, F.V.J., (1999), 'The triumph of instrumental citizenship? Migrations, identities and the nation-state in Southeast Asia'. Asian Studies Review 233.

Assis, M., (2006), “International Migration, Migrant Empowerment and Development Prospects: The Philippines". Paper presented at the Conference Migration and Development: Perspectives from the South, Bellagio, Italy, 10-13 July 2006

CARling, J., (2006), "Interrogating Remittances: Core questions for deeper insight and better policies", Paper presented at the Conference Migration and Development: Perspectives from the South, Bellagio, Italy, 10-13 July 2006.

Castles, S., (2004), 'The factors that make and unmake migration policy', International Migration Review 383.

, (2006), 'Guestworkers in Europe: A Resurrection?' International Migration Review 404.

, (2007). 'Twenty-first century migration as a challenge to sociology', Journal of Ethnic and Migration Studies 33.

Cohen, R., (1995), 'Asian Indentured and Colonial Migration' in Cohen, R. (ed.) The Cambridge Survey of World Migration. Cambridge: Cambridge University Press.

Delgado Wise, R. and Covarrubias, H., (2006), "The Mexico-United States Migratory System: Dilemmas of Regional Integration, Development, and Emigration". Paper presented at the Conference Migration and Development: Perspectives from the South, Bellagio, Italy, 10-13 July 2006

GCIM, (2005), Migration in an Interconnected World: New Directions for Action: Report of the Global Commission on International Migration October, Geneva: Global Commission on International Migration.

HÖNEKOPP, E. and Tayanç, T., (1998). 'Releasing the development potential of return migration: the case of Turkey' in Migration, United Nations Working Group on International Migration (ed.) United Nations Technical Symposium on International Migration and Development, 29 June - 3 July 1998, The Hague, Netherlands: unpublished.

IDC, (2004), Migration and Development: How to Make Migration work for Poverty Reduction, HC 79-II London: House of Commons International Development Committee.

Khadria, B., (2006), "India: Skilled Migration To Developed Countries: Labour Migration To The Gulf". Paper presented at the Conference Migration and Development: Perspectives from the South, Bellagio, Italy, 10-13 July 2006

KRITZ, M.M., Lin, L.L. and Zlotnik, H. (ed.), (1992). International Migration Systems: A Global Approach. Oxford: Clarendon Press. 
LEVITT, P., (1998). 'Social remittances: migration driven local-level forms of cultural diffusion'. International Migration Review 324.

MArtin, P., Mason, A. and Nagayama, T., (1996). 'Introduction to special issue on the dynamics of labor migration in Asia'. Asian and Pacific Migration Journal $52-3$.

, (1991), The Unfinished Story: Turkish Labour Migration to Western Europe. Geneva: International Labour Office.

— and Taylor, J.E., (2001). 'Managing migration: the role of economic policies' in Zolberg, A.R. and Benda, P.M. (eds.), Global Migrants, Global Refugees: Problems and Solution. New York and Oxford: Berghahn.

Noll, G., (2006), The Euro-African Migration Conference: Africa sells out to Europe, Stockholm: Open Democracy, accessed 18 August 2006, www.opendemocracy.net

PORTES, A., Guarnizo, L.E. and Landolt, P., (1999), 'The study of transnationalism: pitfalls and promise of an emergent research field'. Ethnic and Racial Studies 222.

RoDney, W., (1972), How Europe Underdeveloped Africa. London: BogleL'Ouverture

UN Population Division, (2006). International Migration, New York: United Nations Population Division.

Vertovec, S., (2004), 'Migrant transnationalism and modes of transformation'. International Migration Review 383.

World Bank, (2006a), Global Economic Prospects 2006: Economic Implications of Remittances and Migration Washington DC: World Bank. , (2006b), Key Development Data and Statistics, Washington DC: World Bank, accessed 23 January 2006, http://web.worldbank.org/WBSITE/EXTERNAL/DATASTATISTICS/

(2006c), World Development Indicators Database: GNI per Capita. Washington: World Bank, accessed 28 September 2006, http://siteresources.worldbank.org/DATASTATISTICS/Resources/GNIPC.pdf

ZELINSKY, W., (1971), 'The hypothesis of the mobility transition'. Geographical Review 612. 